\title{
Assessment of Ports Competiveness in West and Central African Sub-Regions Using Priest Analytic Hierarchy Process: The Defies \& Incompetence of the Port of Douala (Cameroon)
}

\author{
Veronique Nguele Balla', F. C. Anguibi China² ${ }^{2}$, R. A. N. Fouda ${ }^{3}$, C. D. Bissemb ${ }^{4}$ \\ ${ }^{1}$ Scientific Research Academy, Shanghai Maritime University, Shanghai, China \\ ${ }^{2}$ School of Economics and Management, Shanghai Maritime University, Shanghai, China \\ ${ }^{3}$ Researcher of Logistics Management for Shanghai Maritime University, Shanghai, China \\ ${ }^{4}$ College of Transports \& Communication, Shanghai Maritime University, Shanghai, China \\ Email: v.ballanguele@gmail.com, anguibicarine@hotmail.com,reginemilena@yahoo.com, \\ bissemb_cdelphin@yahoo.com
}

Received 31 December 2015; accepted 26 February 2016; published 29 February 2016

Copyright (C) 2016 by authors and Scientific Research Publishing Inc.

This work is licensed under the Creative Commons Attribution International License (CC BY).

http://creativecommons.org/licenses/by/4.0/

(c) (i) Open Access

\begin{abstract}
Ports play a fundamental role in a sustainable integration of Africa in International trade. Both importers and exporters, shipping companies and government, however face high cost for sea transport and substantial inefficiency in port operations. This has resulted in congestion, higher dwell time, higher costs which affect the competitive ability in sub regional and global economy. This study investigates the main factors explaining poor container handling operations and limited competitive ability in Cameroonian Ports and aggregating this to the competitive position of Cameroonian ports in the West and Central African sub-regions (WCA). Using Analytic Hierarchy Process (A.H.P), the paper seeks to provide a basic understanding of container transportation and port's terminal operations problems (constraints \& ineffectiveness) in Cameroon.
\end{abstract}

\section{Keywords}

Port Competitiveness, WCA, Douala Port, Hard \& Soft Infrastructure, Defies \& Incompetence, AHP, Eigenvector \& Fuzzy Preference Programming 


\section{Introduction}

Container throughputs and ports are implicitly required to provide adequate services, in order to meet their customer's demand or services requirements. Unsatisfied customers, as the case may be, may sometimes be constrained to shift their containers inflow and/or outflow to more competent ports, in response to limits in the service levels provided by their first host port. The result of low service levels is generally an "abandonment” of the port (for a more efficient port). A definition of port competitiveness [1] gives us a better understanding on how this mechanism may translate: "Port competitiveness [...] can be defined as the ability of a port and its vicinity in the creation of value added". Hence creating no value renders a port less competitive to other ports, hereby impacting its credibility and profitability. An extended view of this definition was provided [2], who defined port competitiveness as the performance of a port to create regional or nationwide value-added goods and/or services by producing an industrial clustered effect.

\subsection{Main Objective}

The primary objective of this paper is to assess thoroughly, the competitive position of the port of Douala over selected ports of the sub-region. This is an attempt to evaluate what is done right at the port of Douala (Following sub-regional standards) and what aspect of the port of Douala either needs reform for, or structural upgrade.

\subsection{The Significance of This Paper}

Why study Douala port competitiveness? A justifiable answer lies in the fact that, in the context of Central African countries in general, relatively little studies pertaining to port competitiveness can be traced in the literature. Very recent researches focusing on West and Central Africa attempt to tackle the issue of port efficiency and Competitiveness in the region as witnessed [3] and [4]. This paper is an important contribution to a brilliantly pioneered work in the above mentioned papers. Moreover, identifying and understanding, the strengths and weaknesses of each port from the supply chain perspective may help ports in the West \& Central African regions in general (the port of Douala, in Particular) to adopt a better strategy in order to capitalize on their strengths, mitigate their weaknesses and therefore gain a competitive advantage.

\section{Literature Review}

\subsection{Port Competitiveness in General}

Port competitiveness is an extensive subject studied by various scholars. There exists an enormous amount of literature in this subject matter. The effect of poor port performance on a country's trade has become obvious. The understanding of the attributes of ports or terminals competitiveness is particularly important because they are vital to the economy of the country and the success and welfare of its industries and citizens. Many reasons sustain the fact that, port needs to better understand its competitive environment. The determination of the competitive advantage is not only a powerful strategic tool for port operators, but also constitutes a most informative input for regional and national port planning and operations. The review on port competitiveness has typically centered on ports selection criteria in advanced and emerging markets [5]-[7]. A competitive port is a port that is chosen more regularly than other ports, facilitating the growth of its market share [8]. Competitiveness in general refers to the capacity of a firm to provide efficient production processes, assuring customers' satisfaction as well as company growth, the degree of innovation and the degree to which opportunities can be capitalized upon. Hence, understanding attributes of port competiveness is fundamental to any business, specifically to the port.

Many researchers have analyzed the competitiveness of ports from different angles. In fact, some of them have focused on the opinion of port service suppliers [9], while others have conducted their researches from the user's perspective [10] But, with globalization, today’s maritime environment being characterized with the importance of logistics chain, concentrating only on customer's satisfaction analysis or on services providers view in making strategic decision may be prejudicial for the related port. For instance, Data Envelopment Analysis (D.E.A) used by [11] [12], Regression Analysis [13] Fuzzy multi-criteria grade classification (F.M.G.C Model) used by [1]; Normalized pair-wise estimation (N.P.E) used by [14]; Analytic Hierarchy Process (A.H.P) [15]; [16]; Factors Analysis [17]. These methods of assessment, often coupled with other accompanying methods often provide an insight view of the essence of competitiveness evaluation and broaden the scope for further studies. 


\subsection{Port Norms of Selection}

The ability of port to compete effectively depends on how the factors that affect its attractiveness evolve in relation to their competitors. Misunderstanding these factors may cause waste of resources or/and failure. Port competitiveness determinants can be divided into categories concerning the geographical location, the port physical and technical infrastructures and integrated logistics service in transport chains. The questions therefore to be answered in analyzing port competitiveness are:

i) What are the determinants of port competitiveness according to ports?

ii) Who are the decision makers on port choice and what criteria do they consider?

These questions that obtain pertinent elucidation from Table 1 provide answers to what the determinants of port competitiveness with regards to ports are (providing peculiar examples of ports). On the other hand, Table 2 identifies the decision makers on port choice and what criteria they consider in port choice. Both tables are obtained from [18] and provide a premise to how this paper is being approached.

Table 1. Overview of policy instruments for competitive port (source: compiled by authors with information from [18]).

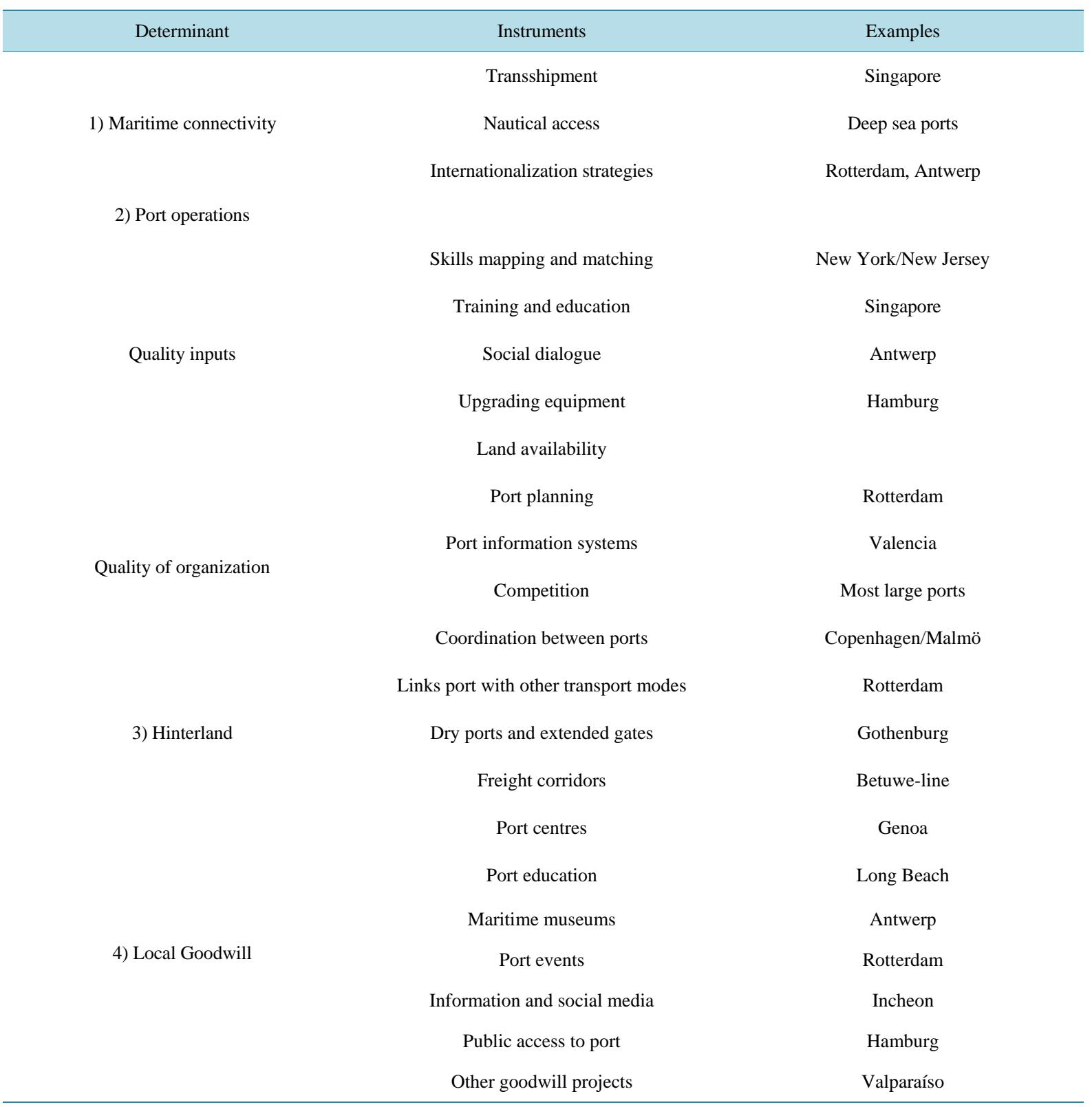


Table 2. Determinant of port choice (source: compiled by authors with information from [18]).

\begin{tabular}{|c|c|c|}
\hline Decision maker on port choice & Port choice criteria (in order of importance) & Sources \\
\hline Shippers & $\begin{array}{l}\text { Costs, port operations quality, port location, frequency } \\
\text { of shipping services, speed/time, service efficiency, } \\
\text { port efficiency, port facilities, port information systems, } \\
\text { hinterland connections, port congestion, port services, } \\
\text { flexibility for special cargo }\end{array}$ & $\begin{array}{l}\text { Slack (1985), Branch (1986), Murphy et al. } \\
\text { (1992), Murphy and Daley (1994), Kumar } \\
\text { and Vijay (2002), Nir et al. (2003), Tiwari } \\
\text { et al. (2003), Malchow and Kanafani } \\
\text { (2001), Malchow and Kanafani (2004), } \\
\text { Song and Yeo (2004), Cullinane et al. } \\
\text { 2005), Guy and Urli (2006), Ugboma et al. } \\
\text { (2006), De Langen (2007), Leachman } \\
\text { (2008), De Martino and Morvillo (2008) }\end{array}$ \\
\hline Forwarders & $\begin{array}{l}\text { Port efficiency, port operations quality, reputation, cost, } \\
\text { frequency, location, speed/time, port information } \\
\text { systems, hinterland connections }\end{array}$ & $\begin{array}{l}\text { Slack (1985), Bird and Bland (1988), } \\
\text { Murphy et al. (1992), Tongzon (1995), } \\
\text { Tongzon and Sawant (2007), De Langen } \\
\text { (2007), Grosso and Monteiro (2008), De } \\
\text { Martino and Morvillo (2008), Tongzon } \\
\text { (2009) }\end{array}$ \\
\hline Shipping Companies & $\begin{array}{l}\text { Cost, port location, port facilities, port operations } \\
\text { quality, speed/time, port efficiency, port congestion, } \\
\text { frequency of shipping services, hinterland links, port } \\
\text { information systems, information availability, port } \\
\text { administration, port services, flexibility for special } \\
\text { cargo }\end{array}$ & $\begin{array}{l}\text { Murphy et al. (1992), Lirn et al. (2004), } \\
\text { Ha (2003), Song and Yeo (2004), Shintani } \\
\text { et al. (2007), De Martino and Morvillo } \\
\text { (2008), Meersman et al. (2008) }\end{array}$ \\
\hline Terminal Operators & $\begin{array}{l}\text { Port facilities, port operations quality, cost, location, } \\
\text { hinterland connections, Port information systems, port } \\
\text { congestion, port efficiency }\end{array}$ & $\begin{array}{l}\text { Song and Yeo (2004), Acosta et al. (2007), } \\
\text { Meersman et al. (2008), Wiegmans et al. } \\
\text { (2008) }\end{array}$ \\
\hline
\end{tabular}

Therefore, port competitiveness in a certain aspect resides on the choice of the adequate comparison norms. The selection of these norms can be considered in various aspect and necessitate an important scrutiny in order to yield appreciable result.

When judging port competitiveness [3] propose a line of thought and the authors say:

"As far as West and Central Africa port logistics is concerned, there are many influential factors of ineffectiveness, e.g. poor hinterland links, outdated machineries, poor infrastructure, inadequate shipping services, benchmarking, low maintenance of port area/zone, port officials' corruption, high custom fees, slow motion in port performance, containerization linger low despite efforts of revival, low capacity, and undeveloped technology".

\section{An Outlook of the Port of Douala}

The Port of Douala is Cameroon's major port, lying at the head of the Wouri estuary about $30 \mathrm{~km}$ from the open sea. Douala is a focal point for both the road and rail systems of the country. Douala possesses the basic infrastructure needed for a port, but the limited depth of water in the long entrance channel is a handicap to port development in view of the trend towards deeper drafts of vessels. Moreover, there is very limited room for expansion because the port is largely hemmed in by the city. The port of Douala moves freight along intraregional corridors in the Central African region (Central Africa Republic and Chad Intermodal Corridors). Its neighboring ports; Port of Owendo (Gabon), Port of Pointe-Noire (Congo), Port of Matabi (DRC) and Port of Luanda (Angola) suffer from high costs of moving goods (twice as much as in southern Africa where distances are significantly longer). Moving a metric ton (tone) of freight from port to hinterland destination costs between $\$ 230$ and $\$ 650$ along intraregional corridors in Central Africa compared with \$120 to \$270 in southern Africa [19]. In fact, transport costs in Central Africa remain among the highest in Sub-Saharan Africa at \$0.11 to \$0.26 per ton-km, compared with \$0.06 to \$0.08 in West Africa (Lomé-Ouagadougou and Cotonou-Niamey) and East Africa (Mombasa-Kigali and Mombasa-Kampala), and (\$0.05 to \$0.06 in Southern Africa (Durban-Lusaka and Durban-Ndola) [20]. 


\section{Assessment of Port Competitiveness in Central Africa}

The method of choice of port competitiveness assessment in this paper is the Analytic Hierarchy Process (A.H.P). This well-known model of Multi-criteria evaluation method has proven to be a very effective method of option selection based on multiple criteria ranking. For more insight on this model, readers are redirected to selected literature such as [21]. The software of chosen to implement AHP in this paper is PriEst. It is a Java Runtime Environment based software developed by [22]. This software offers the user flexibility and convenience in the implementation of AHP.

\subsection{Criteria Selection and Data Collection}

The choice of criteria for this AHP evaluation model resides in the guidance of African ports based papers. The notable ones which fall in line with the objective of this paper are [23] and [3]. Following these, the choice of criteria was made in two groupings, which reflect the capability to maximized potential of ports [23]. These groupings are:

i) The Hard physical infrastructure (Number of berths and state of Superstructure, Average berth draught, Storage capacity, Connectivity (Other transport mode integration)).

ii) The Soft infrastructure (customs services efficiency, Vessel turnaround time (Stevedoring), Average container dwell time).

The selected criteria for evaluation and their abbreviations appear in Table 3.

The criteria were compared in a pairwise manner reflecting their ranking in literature, and also reflecting the authors' point of view. Four neighboring ports to the port of Douala (Port of Owendo (Gabon), Port of Pointe-Noire (Congo), Port of Matabi (DRC) and Port of Luanda (Angola)) were assessed compared to the criteria selected. Three additional West African Ports (Port of Apapa (Lagos), Port of Abidjan (Cote d'Ivoire) and Port of Tema (Ghana)) were introduced during the data collection (But not during the evaluation) in order to provide a relative perspective between Central African ports and West African ports. The collection of data (and successive ranking of data collected) and the raking of selected criteria enabled the authors to have the necessary base-data for implementation of the Analytic Hierarchy Process in the Java Runtime Environment PriEst module. The summarized and ranked data appear in Figure 1.

\subsection{Analytic Hierarchy Process (AHP)}

The initial step in the AHP evaluation for this research resided into developing the Hierarchy structure of the study. Figure 2 below shows this structure:

The pairwise comparison between the selected criteria is made following a standardized scale of preference. This scale which is widely used in AHP evaluation appears in the Table 4.

The following part of the evaluation consisted in entering the pairwise comparison matrix of the selected criteria in the software PriEst. This enabled calculation of the weights of each selected criterion (and sub-criterion) hence permitting us to obtain criteria ranking. The pairwise comparison matrix used is shown in Table 5.

The pairwise comparison matrix was inputted in the PriEst software yielding a consistency ratio (CR) of 0.082. The value of CR (0.082) being less than 0.1 we judged the solution to weights, as acceptable and hence considered them for further evaluation. Table 5 shows the criteria (sub-criteria) ranking obtained from PriEst elicitation.

The information gathered on the five ports hereafter evaluated is summarized in Table 6 and Table 7. This information is the bases for the ranking of the ports criteria-wise in Figure 1. The overall compilation of data enabled the result explicitated in Section 4.3.

Table 3. Abbreviation of criteria (source: authors).

\begin{tabular}{cc} 
Criteria & ABBREVIATION \\
Number of berths (1A-1) and type and state of the superstructure (1A-2) & 1A \\
Average berth draught & $2 \mathrm{~B}$ \\
Storage capacity & $3 \mathrm{C}$ \\
Connectivity (Other transport mode integration) & $4 \mathrm{D}$ \\
Turnaround time (CQD) & $5 \mathrm{E}$ \\
Average container Dwell time & $6 \mathrm{~F}$ \\
Customs procedure & $7 \mathrm{G}$ \\
\hline
\end{tabular}


Table 4. Pairwise values for comparison and their interpretation (source: authors).

\begin{tabular}{cc}
\hline VALUE & INTERPRETATION \\
\hline 1 & Criteria A is equally important to criteria B \\
3 & Criteria A is weakly important to criteria B \\
5 & Criteria A is strongly important to criteria B \\
7 & Criteria A demonstrates strong importance to criteria B \\
9 & Criteria A is absolutely important to criteria B \\
$2,4,6,8$ & Criteria A has intermediate importance (Between Adjacent values) to Criteria B \\
\hline
\end{tabular}

Table 5. Pairwise comparison for criteria and sub-criteria matrix (source: authors data compilation).

\begin{tabular}{|c|c|c|c|c|c|c|c|}
\hline & 1A & 2B & $3 C$ & 4D & $5 E$ & $6 F$ & $7 \mathrm{G}$ \\
\hline $\mathbf{1 A}$ & 1 & $1 / 5$ & $1 / 3$ & $1 / 9$ & $1 / 2$ & $1 / 7$ & $1 / 7$ \\
\hline $2 B$ & 5 & 1 & 2 & $1 / 8$ & 3 & $1 / 6$ & $1 / 6$ \\
\hline $3 C$ & 3 & $1 / 2$ & 1 & $1 / 6$ & 2 & $1 / 3$ & $1 / 3$ \\
\hline 4D & 9 & 8 & 6 & 1 & 7 & 5 & 5 \\
\hline $5 E$ & 2 & $1 / 3$ & $1 / 2$ & $1 / 7$ & 1 & $1 / 4$ & $1 / 4$ \\
\hline $6 F$ & 7 & 6 & 3 & $1 / 5$ & 4 & 1 & 1 \\
\hline \multirow[t]{2}{*}{$7 G$} & 7 & 6 & 3 & $1 / 5$ & 4 & 1 & 1 \\
\hline & 1A-1 & 1A-2 & & & & & \\
\hline 1A-1 & 1 & 5 & & & & & \\
\hline 1A-2 & 0.2 & 1 & & & & & \\
\hline
\end{tabular}

\begin{tabular}{|c|c|c|c|c|c|c|c|c|c|c|c|c|c|c|c|c|c|c|c|c|c|}
\hline Data & & $6 \mathrm{~F}$ & Data & & $5 E^{*}$ & Data & & 4D & Grading & & $3 \mathrm{C}$ & Data & & 2B & Data & & & & IA & & \\
\hline $\begin{array}{l}114 \mathrm{TH} \\
(2.37)\end{array}$ & 1st & Ovendo & 10+Days & 1st & Apapa & $1.5+$ Days & 1st & Douala & 5 & 1st & Tema & $\begin{array}{c}20.000 \\
\text { TEUs }\end{array}$ & 1st & Luanda & $\begin{array}{c}\text { Over } \\
23.2 \mathrm{~m}\end{array}$ & 1st & Abidjan & $\begin{array}{c}26 \\
(5+)\end{array}$ & 1st & Abidjan & 11 \\
\hline $\begin{array}{l}117 \mathrm{TH} \\
(2.35)\end{array}$ & 2nd & Abidjan & 12 Days & 2nd & Tema & $\begin{array}{l}\text { 1.5 Days }+ \\
14.2 \text { Hours }\end{array}$ & 2nd & Abidjan & 5 & 2nd & Abidjan & $\begin{array}{c}20.000 \\
\text { TEUs }\end{array}$ & 2nd & $\begin{array}{l}\text { Pointe } \\
\text { Noire }\end{array}$ & $15.2 \mathrm{~m}$ & 2nd & Apapa & $\begin{array}{l}22+ \\
\text { (4) }\end{array}$ & 2nd & Tema & 9 \\
\hline $\begin{array}{l}120 \mathrm{TH} \\
(2.33)\end{array}$ & 3 rd & Luanda & 12+Days & 3 rd & Abidjan & 2 Days & 3 rd & Matabi & 5 & 3 rd & Douala & $\begin{array}{l}16.500 \\
\text { TEUs }\end{array}$ & $3 \mathbf{r d}$ & Apapa & $13.5 \mathrm{~m}$ & 3 rd & Douala & $18(3)$ & 3 rd & Matabi & 8 \\
\hline $\begin{array}{l}130 \mathrm{TH} \\
(2.22)\end{array}$ & 4th & $\begin{array}{l}\text { Pointe } \\
\text { Noire }\end{array}$ & 18 days & 4th & Matabi & 2+Days & 4th & Арара & 3 & 4th & $\begin{array}{l}\text { Pointe } \\
\text { Noire }\end{array}$ & $\begin{array}{l}14.100 \\
\text { TEUs }\end{array}$ & 4th & Tema & $12.5 \mathrm{~m}$ & 4th & Tema & $14(2)$ & 4th & $\begin{array}{l}\text { Pointe } \\
\text { Nire }\end{array}$ & 6 \\
\hline $\begin{array}{c}148 \mathrm{TH} \\
(2.00)\end{array}$ & 5th & Douala & 18+Days & 5th & Ovendo & $2.5+$ Days & 5th & Tema & 3 & 5th & Luanda & $\begin{array}{l}11.166 \\
\text { TEUs }\end{array}$ & 5th & Abidjan & $\begin{array}{c}11.50 \\
\mathrm{~m}\end{array}$ & 5th & Luanda & $11(3)$ & 5th & Арара & 6 \\
\hline $\begin{array}{l}156 \mathrm{TH} \\
(1.86)\end{array}$ & 6th & Tema & $20+$ days & 6th & $\begin{array}{l}\text { Pointe } \\
\text { Noire }\end{array}$ & 4.1 Days & 6th & Ovendo & 2 & 6th & Matabi & $\begin{array}{l}6000 \\
\text { TEUs }\end{array}$ & 6th & Ovendo & $9-11 \mathrm{~m}$ & 6th & Matabi & $10(3)$ & 6th & Ovendo & 6 \\
\hline $\begin{array}{l}158 \mathrm{TH} \\
(1.78)\end{array}$ & 7th & Matabi & $\begin{array}{l}22-28 \\
\text { Days }\end{array}$ & 7th & Douala & 4.8 Days & 7th & $\begin{array}{l}\text { Pointe } \\
\text { Noire }\end{array}$ & 2 & 7th & Ovenda & $\begin{array}{l}2500 \\
\text { TEUs }\end{array}$ & 7th & Matabi & 9-10 m & 7th & $\begin{array}{l}\text { Pointe } \\
\text { Noire }\end{array}$ & $11(2)$ & 7 th & Luanda & 5 \\
\hline $\begin{array}{l}160 \mathrm{TH} \\
(1.50)\end{array}$ & 8th & Apapa & 42 Days & 8th & Luanda & 6+ Days & 8th & Luanda & 1 & 8th & Apapa & $\begin{array}{l}\text { Non- } \\
\text { Existant }\end{array}$ & 8th & Douala & $7.6 \mathrm{~m}$ & 8th & Ovendo & $3(3)$ & 8th & Douala & 2 \\
\hline
\end{tabular}

Figure 1. Data pertaining to AHP ranking/source: compiled by authors with information from [19] [20] [24]-[30].

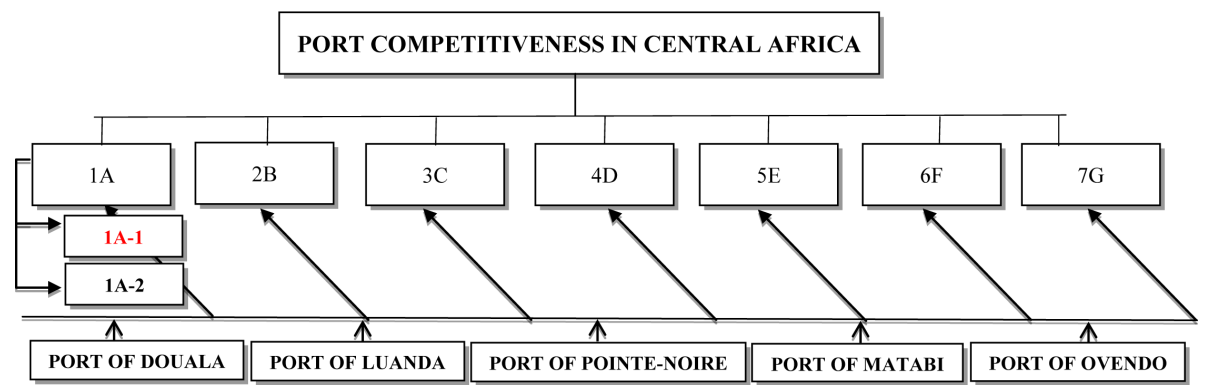

Figure 2. Hierarchy structure (source: authors). 
Table 6. Weights and rank of criteria and sub-criteria (source: PriEst software as compiled by authors).

\begin{tabular}{cccccccc}
\hline Criteria & $\mathbf{1 A}$ & $\mathbf{2 B}$ & $\mathbf{3 C}$ & $\mathbf{4 D}$ & $\mathbf{5 E}$ & $\mathbf{6 F}$ & $\mathbf{7 G}$ \\
\hline Weights & 0.024 & 0.066 & 0.061 & 0.456 & 0.04 & 0.177 & 0.177 \\
Rank & $6^{\text {th }}$ & $3^{\text {rd }}$ & $4^{\text {th }}$ & $1^{\text {st }}$ & $5^{\text {th }}$ & $2^{\text {nd }}$ & $2^{\text {nd }}$ \\
& & & & & & \\
Sub-Criteria & $\mathbf{1 A - 1}$ & $\mathbf{1 A - 2}$ & & & & \\
Weights & 0.833 & 0.167 & & & & \\
Rank & $1^{\text {st }}$ & $2^{\text {nd }}$ & & & & \\
\hline
\end{tabular}

Table 7. Compiled information used for option's ranking (source: compiled by authors).

\begin{tabular}{|c|c|c|c|c|c|c|c|c|c|}
\hline & & \multicolumn{8}{|c|}{ CRITERIA (SUB-CRITERIA) } \\
\hline & & \multicolumn{2}{|l|}{$1 \mathbf{A}^{[\mathrm{i}]}$} & \multirow[b]{2}{*}{ 2B (m) } & \multirow[b]{2}{*}{ 3C ${ }^{[i i i]}$ (TEUs) } & \multirow[b]{2}{*}{ 4D } & \multirow[b]{2}{*}{$5 \mathbf{E}^{[\mathrm{iv}]}$} & \multirow[b]{2}{*}{$6 F$} & \multirow[b]{2}{*}{$7 G$} \\
\hline & & $\begin{array}{l}\text { 1A-1 }{ }^{[\mathrm{iij}]} \text { Number } \\
\text { of berths }\end{array}$ & 1A-2 & & & & & & \\
\hline \multirow{8}{*}{ PORTS } & DOUALA & $18(3)$ & 2 & $7.6 \mathrm{~m}$ & 16.500 TEUs & 5 & $3.2+1.6$ days & $18+$ days & $6^{\text {th }}$ \\
\hline & LUANDA & $11(3)$ & 5 & Over $23.2 \mathrm{~m}$ & 11.166 TEUs & 1 & $\begin{array}{c}(4+\text { days }) \\
\text { days })\end{array}$ & $12+$ days & $1^{\mathrm{st}}$ \\
\hline & APAPA & $22+(4)$ & 6 & $13.5 \mathrm{~m}$ & Non-existent ${ }^{[\mathrm{iv}]}$ & 3 & 1 day +0.5 day & 42 days & $2^{\text {nd }}$ \\
\hline & CONGO & $11(2)$ & 6 & $15.2 \mathrm{~m}$ & 14.100 TEUs & 2 & 2.5 days +1.6 days & 18days & $8^{\text {th }}$ \\
\hline & DRC & $10(3)$ & 8 & $9.1 \mathrm{~m}-10$ & 6000 TEUs & 5 & $?+2+$ days & 22 - 28 days & $7^{\text {th }}$ \\
\hline & GABON & $3(3)$ & 6 & $9-11 \mathrm{~m}$ & 2500 TEUs & 2 & $(1.5+$ days $)+1$ day & $10+$ days & $5^{\text {th }}$ \\
\hline & TEMA & $14(2)$ & 9 & $12.5 \mathrm{~m}$ & 20.000 TEUs & 3 & 1.5 days +14.2 hours & 20 + days & $4^{\text {th }}$ \\
\hline & ABIDJAN & $26+(5)$ & 11 & $11.50 \mathrm{~m}$ & 20.000 TEUs & 5 & 1 day +1 day & 12 days & $3^{\text {rd }}$ \\
\hline
\end{tabular}

[i] Criteria 1A is subdivided into two sub-criteria Number of berths (1A-1) and Type of Superstructure (1A-2); [ii] Total number of berths (Container Berths) (Ex: Port of Douala 18(3)); [iii] Container storage capacity (Excluding empty container storage); [iv] Turnaround time (Container vessels) = Average waiting time + Average vessel stay time; [v] The storage is not in the vicinity of the port.

\subsection{Results and Comments}

The data were assessed in PriEst AHP evaluation software using two methods of AHP evaluation, notably Eigenvector and Fuzzy Preference Programming. These results are explicitated in Table 8 and Table 9. The PriEst ranking evaluation yielded the following results for the five selected ports (Figure 2). The results obtained and displayed in Figure 2, yield a surprising ranking. The port of Douala ranks as first, hence being the most competitive port in the region of Central Africa. Despite its numerous challenges (Section 5) the port of Douala happens to have undeniable structural advantages compared to other central African Ports. This can be explained by the extensive (Even though archaic as compared to developed countries) intermodal connectivity of port of Douala and the relatively important storage capacity in the port of Douala which gives it a relatively remarkable advantages over other ports in the sub-region. Nevertheless, it is important to note that the port of Douala still suffers from an important lag in the central African port industry (which we wish to extend to the West African and Central African Port industry).

Table 8. Results obtain using eigenvector method (source: compiled by authors).

\begin{tabular}{cccc}
\hline Ports & Weights & AHP Ranking \\
\hline Port of Douala & 0.255 & $1^{\text {st }}$ \\
Port of Matabi & 0.226 & $2^{\text {nd }}$ \\
Port of Luanda & 0.225 & $3^{\text {rd }}$ \\
Port of Ovendo & 0.187 & $4^{\text {th }}$ \\
Port of Pointe-Noire & 0.107 & $5^{\text {th }}$ \\
\hline
\end{tabular}


Table 9. Results obtain using Fuzzy preference programming method (source: compiled by authors).

\begin{tabular}{ccc}
\hline Ports & Weights & AHP ranking \\
\hline Port of Douala & 0.244 & $1^{\text {st }}$ \\
Port of Matabi & 0.236 & $2^{\text {nd }}$ \\
Port of Luanda & 0.194 & $3^{\text {rd }}$ \\
Port of Ovendo & 0.171 & $4^{\text {th }}$ \\
Port of Pointe-Noire & 0.154 & $5^{\text {th }}$ \\
\hline
\end{tabular}

\section{The Defies and Incompetence of the Port of Douala}

There are numerous documented challenges faced by the Port of Douala which renders it non-competitive in the sub-region of Central Africa and on the extended West Africa coastline. For the purpose of this paper, few will be cited.

- Port and cargo-handling costs in the port of Douala are at the higher end of charges as paid along the West African coastline. The handling charge is \$220 per TEU for containers and \$6.5 per ton of general cargo. More generally, the charges levied in Central African ports do not compare favorably with the rest of Africa; let alone with global best practice. The services provided by central and West African ports generally cost twice as much as those in other global ports.

- Moreover, the port of Douala is not yet ISPS-code compliant. In 2006 the port introduced a container-scanning device. At the beginning of 2007 new automated customs procedures went into effect. However, the authorities estimate that it will still take a number of years to exit the ISPS blacklist.

- One of the major problems in approaching/departing Douala is the change of channel depths due to river silting in a relatively narrow channel. Also, navigational problems are recurrently reported in relationship with poorly aligned buoys.

- No marine forecasts are issued for Douala.

The list of challenges, an apparently non-exhaustive one, only depicts the inefficiency of the Port of Douala in a global way. But it is important to keep in mind that, the AHP evaluation depicted in this research ranks the port of Douala against neighboring ports in the sub-region of Central Africa (Ports which may have similar problems and stance). The question hence is: What is the importance (apart from the obvious ones already stated in this paper) of ranking central African ports? The answer lies in the perception that port users have of African port in general. In literature, Central African ports happen to be reflected as the less coveted ports in Africa. Ranking ports in this region hence provide us with a new approach to look at Central African port, and creates a base for comparison between the "Best" central African port(s) and ports in other regions such as West, South, East and North Africa. In recent literature [31] analysis six ports in the sub-region of West Africa in terms of efficiency. The port of Abidjan (Cote d'Ivoire) in this study transpires as one of the best in West Africa. This study follows the line of the results compiled in Figure 1 and hence justifies the introduction of the port of Abidjan in the following section as a Model port.

\section{An African Model Port with Lucrative Service Standards: Port of Abidjan}

Côte d'Ivoire has launched massive upgrades to its ports to support the growth of the natural resource sector and to attract more of the regional transit trade. Their actual project involves the construction of a second container terminal, the expansion of a minerals terminal and the enlargement of the Vridi Canal. The plans will enable the port to handle $2.25 \mathrm{~m}$ twenty-foot equivalent units (TEUs), which would make it the port with the largest capacity in West Africa. The Port Autonomed' Abidjan recorded a traffic increase of 7\% in 2013, which is a provisional figure that does not include oil shipments. In 2012, it handled $21.7 \mathrm{~m}$-ton, a 31\% rise from the $16.6 \mathrm{~m}$-ton recorded in 2011. Container traffic also expanded 16\% over the same period to 633,917 TEUs. These figures (summarized in Table 10) are expected to rise even more. As the economy of the world's largest cocoa producer 
Table 10. Port infrastructure, capacity and facilities (source: compiled by authors).

\begin{tabular}{cccc}
\hline PERIOD & TEUs & Average (Before) $\%$ & Average (Now) $\%$ \\
\hline 2013 & $2,025,000$ & - & $16 \%$ \\
2011 & 633,917 & $7 \%$ & - \\
2012 & $21,007,000$ & - & $31 \%$ \\
2011 & $16,006,000$ & $17 \%$ & - \\
\hline
\end{tabular}

is bouncing back following the end of a decade-long political and social crisis in 2011, gross domestic product growth reached 9\% in 2013. Moreover, the director says their goal is to "reposition our port and give it the opportunity to fully play its role to the benefit of the national and regional economy".

Despite criticism from many economic operators, who are worried about high costs due to the lack of competition, the government said the new terminal will improve the harbor's competitiveness and lower the prices by as much as $40 \%$. Among the other upgrade projects is the minerals terminal, which will be expanded to meet demand from the booming mining sectors in Burkina Faso, Côte d'Ivoire and Mali. Furthermore, port authorities aim to handle $3 \mathrm{~m}$-ton of minerals, including manganese and zinc by 2020 (up from 300,000 tn of current statistics). In the meantime, the western port of San Pedro, the country's main port for cocoa exports, also aims to expand and boost its traffic by increasing transshipments and attracting cotton and cashew exports away from the port of Abidjan. However, the port has forecast that traffic will rise to $31 \%$ that is, $4.2 \mathrm{~m}$-ton from $3.2 \mathrm{~m}$-ton a year earlier. Transshipments were also set to increase to $2.8 \mathrm{~m}$-ton from $1.9 \mathrm{~m}$-ton. In 2012, the harbor has begun to ship cotton from Mali and handled 21,000 tn of the commodity last year while boosting exports of cashews to 17,000 tn from $2000 \mathrm{tn}$. The port authorities targeted a goal of 4.5-5 m-ton of goods in 2014, and as much as $10 \mathrm{~m}$-ton in 2015.

\section{Strategic Analysis \& Recommendations}

African ports (in general) cannot be secluded from world trends in trade and shipping. So far, most African ports have not been able to be incorporated into global trends. Yet, their current defies may be an opportunity, as their developments should over time result in more efficient port and transport operations.

- To reduce dwell times and handling costs, countries in Africa (especially Douala port) need to invest in information systems, communications technology, and modern customs practices. Customs procedures, in particular, act as a bottleneck to port efficiency when they are outdated or open to corruption. As an extreme example, one port had to close for an extended period because of customs problems. Modern customs procedures and other soft infrastructure have a major role in delivering efficient port and freight transportation systems.

- Striving for efficient ports must be complemented by associated measures to increase transparency and reduce corruption in customs administration. The African ports, like all world ports, must create port community systems not only to improve productivity and efficiency (and thereby reduce costs), but also to respond to the growing importance of and future obligation in supply chain security.

- Regarding the hub and spoke discussion, a single hub port for West Africa and Central Africa is improbable. No country has adequate traffic to become the unique hub in the region. Besides, shipping companies will be strongly induced by the need to provide alternative ports in case of emergency or security problems (case of Douala Port).

- As additional modern container terminals are provided, a more complex pattern will perhaps evolve, with different shipping lines selecting principal ports for their services depending on commercial and trade factors as well as port efficiency.

- Several African ports (case of Douala port) may risk to be increasingly served by transshipment. Some ports will receive the larger ships; others will be served by transshipment in feeder vessels. South African ports should play a major role with an increasing use of transshipment, especially for services from Asia and Australasia. With the rapid development of the South African ports, mainline services from Asia may turn round at Durban, with feeder services to West Africa.

- Large ports in the region with substantial hinterland traffic should be the natural competitors to become hub ports (see Pálsson (1998)). 
- However, medium-size ports (like the Douala Port) in the region could also be serious competitors for becoming hubs in West \& Central Africa. Indeed, decisions on transshipment centers of the latter, will reflect a wide range of additional business considerations by ocean carriers, including the capacity of the ports to handle significantly increased traffic, draft and infrastructure consideration, productivity to diminish turnaround time and country stability.

\section{Conclusion}

Even though there are so many inefficiencies at the port of Douala; compared to other ports on the west coast of Africa (Central Africa region especially), the Port of Douala is one of the most competitive, particularly in terms of connectivity and port capacity. But still it lags behind the average port in Sub-Saharan Africa. Container crane productivity, container dwell time and vessel turnaround time happen to justify the lag of the port of Douala on the West African coastline. In the cargo sectors, performance is consistent with the norms for the region and, as such, there is room for significant improvement as the performance of the ports in this part of the continent trails the average for Sub-Saharan Africa port. Expansion of the port might help to improve the performance of the port of Douala. It was important to mention that this paper's evaluation methodology, analytic hierarchy process was undertaken following Hard and Soft infrastructural criteria on five selected ports of Central Africa. Further investigation in terms of other criteria seems to be the orientation to follow in future papers pertaining to this topic. Criteria grouping in terms of Users (Shippers, Consignees and Ship-owners) are the way forward in future research. This will provide a relative competitive evaluation of ports in the sub-region of Central Africa. On another line of vision, more work needs to be implemented in further port ranking, taking into account cross regional competitiveness in Africa. This will shed additional light on the actual state of port efficiency and port competitiveness in Africa as a whole.

\section{References}

[1] Huang, W.-C., Teng, J.-Y., Huang, M.-J. and Kou, M.-S. (2003) Port Competitiveness Evaluation by Fuzzy Multicriteria Grade Classification Model. Journal of Marine Science and Technology, 11, 53-60.

[2] Teng, J.-Y., Huang, W.-C. and Huang, M.-J. (2004) Multicriteria Evaluation for Port Competitiveness of Eight Asian Container Ports. Journal of Marine Science and Technology, 12, 256-264.

[3] Fouda, R.A.N., Romeo, N.D., Azizi, M. and Fernandez, S.R. (2014) Port Logistics in West and Central Africa: A Strategic Development under Globalization. Open Journal of Applied Sciences, 4, 76-84. http://dx.doi.org/10.4236/ojapps.2014.42009

[4] Fouda, R.A.N. (2014) Empirical Result: West and Central Africa Standardization on Port Logistics. International Journal of Trade, Economics and Finance, 5, 263-269. http://dx.doi.org/10.7763/IJTEF.2014.V5.382

[5] Malchow, M. and Kanafani, A. (2001) A Disaggregate Analysis of Factors Influencing Port Selection. Maritime Policy \& Management, 28, 265-277. http://dx.doi.org/10.1080/03088830110060840

[6] Nir, A.-S., Lin, K. and Liang, G.-S. (2003) Port Choice Behavior from the Perspective of the Shipper. Maritime Policy \& Management , 30, 165-173. http://dx.doi.org/10.1080/0308883032000069262

[7] Ugboma, C., Ugboma, O. and Ogwude, I.C. (2006) An Analytic Hierarchy Process (AHP) Approach to Port Selection Decisions-Empirical Evidence from Nigerian Ports. Maritime Economics \& Logistics, 8, 251-266. http://dx.doi.org/10.1057/palgrave.mel.9100160

[8] Organisation for Economic Co-Operation and Development (2011) Competition Concerns in Ports and Port Services. https://www.ftc.gov/sites/default/files/attachments/us-submissions-oecd-and-other-international-competition-fora/1106 usroundtable.pdf

[9] Acosta, M., Coronado, D. and Cerban, M.D.M. (2011) Bunkering Competition and Competitiveness at the Ports of the Gibraltar Strait. Journal of Transport Geography, 19, 911-916. http://dx.doi.org/10.1016/j.jtrangeo.2010.11.008

[10] Ng, A.Y. and Gujar, G.C. (2009) Government Policies, Efficiency and Competitiveness: The Case of Dry Ports in India. Transport Policy, 16, 232-239. http://dx.doi.org/10.1016/j.tranpol.2009.08.001

[11] Jayanthi, S., Kocha, B. and Sinha, K.K. (1999) Competitive Analysis of Manufacturing Plant: An Application to the US Processed Food Industry. European Journal of Operational Research, 118, 217-234. http://dx.doi.org/10.1016/S0377-2217(99)00022-3

[12] Wu, J., Yan, H. and Liu, J. (2009) Groups in DEA Based Cross-Evaluation: An Application to Asian Container Ports. Maritime Policy \& Management, 36, 545-558. http://dx.doi.org/10.1080/03088830903346095 
[13] Tongzon, J.L. (1995) Determinants of Port Performance and Efficiency. Transportation Research Part A: Policy and Practice, 29, 245-252. http://dx.doi.org/10.1016/0965-8564(94)00032-6

[14] Brooks, M.R., Schellinck, T. and Pallis, A.A. (2011) A Systematic Approach for Evaluating Port Effectiveness. Maritime Policy and Management, 38, 315-334. http://dx.doi.org/10.1080/03088839.2011.572702

[15] Lirn, T.C., Thanopoulou, H.A., Beynon, M.J. and Beresford, A.K.C. (2004) An Application of AHP on Transhipment Port Selection: A Global Perspective. Maritime Economics \& Logistics, 6, 70-91. http://dx.doi.org/10.1057/palgrave.mel.9100093

[16] Yang, Y.B., Yang, Z.Z., Yan, Z. and Zuo, Z. (2005) Evaluation of Competition Ability and Market Share for Container Ports. Proceedings of the Eastern Asia. Society for Transportation Studies, 5, 2483-2493.

[17] Chen, T. (2008) Application of Grey Relational Analysis Based on AHP in the Evaluation of Enterprise Competitiveness. Journal of Neijiang Normal University, No. 8, 016.

[18] OECD (2010) The Competitiveness of Global Port-Cities: Synthesis Report. Edited by Olaf Merk.

[19] Raballand, G., Refas, S., Beuran, M. and Isik, G. (2012) Why Does Cargo Spend Weeks in Sub-Saharan African Ports?: Lessons from Six Countries. World Bank Publications, Washington DC. http://dx.doi.org/10.1596/978-0-8213-9499-1

[20] Ocean Shipping Consultant Ltd. (2009) Beyond the Bottleneck: Ports in Africa. Country Annex, Africa Infrastructure Country Diagnosis (AICD) Background Paper 8.

[21] Arvis, J.-F., Saslavsky, D., Ojala, L., Shepherd, B., Busch, C. and Raj, A. (2014) Connecting to Compete 2014: Trade Logistics in the Global Economy. The Logistics Performance Index and Its Indicators, World Bank.

[22] Siraj, S., Leonelli, R.C., Keane, J.A. and Mikhailov, L. (2013) Priest: A Tool to Estimate Priorities from Inconsistent Judgments. 2013 IEEE International Conference on Systems, Man, and Cybernetics (SMC), Manchester, 13-16 October 2013, 44-49.

[23] AfricanBank 2010, Chapter 2: Port Development in Africa, p. 32.

[24] Port Report Africa Series (Quarter I, 2014), for Port of Douala, Port of Luanda, Port of Pointe-Noire, Port of Matadi, Port of Abidjan, Port of Libreville, Port of Tema, Port of Lagos.

[25] Port autonome de Douala. http://www.portdedouala-cameroun.com

[26] Megalog. http://www.megalog.com

[27] http://www.searates.com

[28] Meersman, H., Van de Voorde, E. and Vanelslande, T. (2010) Port Competition Revisited. Review of Business and Economics, 55, 210-232.

[29] Rakine, G. (2013) Benchmarking Container Terminal Performance. ContainerPort Conference, Rotterdam, 22 February 2013.

[30] Bray, J. (2013) Stuck in the Bottleneck: Corruption in African Ports. Control Risk.

[31] Van Dyck, G.K. (2015) Assessment of Port Efficiency in West Africa Using Data Envelopment Analysis. American Journal of Industrial and Business Management, 5, 208-218. http://dx.doi.org/10.4236/ajibm.2015.54023 